the neglect of genito-urinary work at our large London general hospitals, the teaching on such subjects as syphilis and gonorrhoea having been lamentable, and the opportunities of students for obtaining first-hand knowledge meagre in the extreme. Consider seriously this advice given to a patient of mine, an officer under treatment in one of our largest naval hospitals, "Massage your own prostate daily" - surely a feat within the compass only of the domestic cat. I am, Sir, yours faithfully,

Grafton-street, W., March 13tb, 1918.

Rolf Creasy.

\section{THE LIBRARY OF THE ROYAL SOCIETY OF MEDICINE.}

To the Editor of THE LANCET.

SIR,-I notice in your article on Medical Libraries in last week's issue that you refer to this library as having so many duplicates, that some readers have misunderstood it as depreciating the net value of our stock, and I would ask your kind permission to refer to the matter. I have consulted our librarian, Mr. Hewitt, and he states that while it is true we have a considerable number of duplicates, we have not, as would appear to be suggested, triplicates and quadruplicates, and most of the duplicates we do possess are of books over 20 years old. On the suggestion of Dr. Arthur Latham, honorary secretary of the Amalgamation Committee, who did so much to achieve the amalgamation, we have been trying to form a reference, as well as a circulating, library, and we try to get duplicates of all important books, and these are specially labelled and reserved "for reference only." Of important new books, I am glad to say, we have often in circulation as many as half-a-dozer copies, but we only buy one and hire the others, and exchange these for others as soon as the demand falls off ; but of duplicates in our permanent stock I doubt if we have 2000 .

I am, Sir, yours faithfully,

J. Y. W. MACALISTER.

1, Wimpole-street, London, W., March 18th, 1918.

* * Our annotation was certainly not intended to convey that the admirable library of the Royal Society of Medicine was encumbered with duplicates. - ED. I.

\section{THE NATIONAL SPIRIT OF THE MEDICAL AND TEACHING PROFESSIONS.}

\section{To the Editor of THE LANOET.}

SIR,-Mr. Bonar Law, speaking in the House of Commons on March 7th, said he did not believe the spirit of this country was weakening in the war and that if the question could be put, " Are you prepared to go on with the war until the results you set out to achieve have been attained, or are you not?" the response would be astonishing alike to our enemies and ourselves.

Mr. Bonar Law's question was a challenge to a certain attitude of mind amongst Parliamentarians which is disturbing to many people in these critical times. Debates in the House do not convey the idea of a solidly united nation. Carping criticism, undercurrents of party feeling, and intrigue find expression. Certain Members of Parliament forget their representative character, so long is it since they faced an election. We want to tell them that the nation is determined to see this thing through. In a sense everyone is war-weary, but the aims of the Allies have been put in almost identical terms by the Government, the Labour party, and President Wilson, and we only need the endorsement of the whole people.

It has occurred to us that the medical and teaching professions are in an exceptionally good position to initiate a response to Mr. Law's question. Neither of these professions can be described as capitalist. Their members are seldom keen party politicians and their international interests have long been such as to make a narrow nationalism impossible to them.

Plans for reconstruction after the war also demand attention. Unless there is a satisfactory peace these plans will be brought to naught, and we shall have to prepare for the next war, which German writers are already discussing. The members of both our professions, being brought into contact with all sorts and conditions of men and homes, are well able to realise the great need there is for these schemes of reconstruction. The cry for reforms is in the air, but

there is also the chance that even after a satisfactory peace we may settle down as before without tackling the crying evils in our midst, hence the need for a declaration of policy on this point.

We suggest that these two professions should take steps to arrange for meetings to be held throughout the country on Impire Day, to be presided over by the Lord Mayor, mayors, and chairmen of county councils, for the purpose of giving the Government an answer to the question of the Chancellor of the Exchequer and, further, for the purpose of pledging the nation to the execution of such reforms as are needed to bring abjut that better country which shall be a noble and lasting memorial of those of our countrymen who have laid down their lives for what we believe to be the most sacred cause which ever sent a nation to war.

Practically our suggestions are these :-

1. That the members of the medical and teaching pro fessions in every county and county borough should approach the elected head of their local government area and reques him to call a public meeting.

2 . That at this public meeting two resolutions should be submitted. The first would express the determination of the country to secure a satisfactory peace; the second would pledge the country to far-reaching schemes of reconstruction after peace is declared.

Joseph Batey,

Head Master, Carter Knowle Council School.

ISABEL CLEGHORN,

Past President of the National Union of Teachers.

Charles W. Cotven,

Hon. Secretary, Sheffield Branch of the Nationsl

A. W. Forrest,

Hou. Secretary, Local Medical War Committee.

\section{J. A. Greer}

Professor of Edncation; Dean ff the Faculty of Arts.

J. H. HICHENS,

Head Master. King Edward VII. School.

Sheffield, March 18th, 1918.

\section{URBAN VITAL STATISTICS}

(Week ended March 16th, 1918.)

English and Welsh Towns.-In the 96 English and Welsh towns, with an aggregate civil population estimated at nearly $17,000,000$ person the annual rate of mortality was 16.6 , against 15.7 and 16.7 per 1000 in the two preceding weeks. In London, with a population exceeding $4,000,000$ persons, the death-rate was $17 \cdot 8$, or 0.3 per 1000 above that recortled in the previous weok; among the remainin towns the rates ranged from 6.7 in Smethwick, 7.0 in southend on-Sea, and $7 \cdot 2$ in Ilford to 23.6 in Norwich and in Bath, 24.9 in Swindon, and $39 \cdot 2$ in Barnsley. The principal epidemic diseas caused 614 deaths, which corresponded to an annual rate 1.9 per 1000 , and included 244 from measles, 231 from whoopin 1.9 per 1000 , and included 244 from measles, 231 from whooping
cough, 68 from diphtheria, 55 from infantile diarrhoes, 9 from cough, 68 from diphtheria, 55 from infantile diarrhoea, 9 from carlet fever, and 7 from enteric fever. Measles caused a deathrate of 4.0 in Stoke-on-Trent, 4.3 in Swansea, 5.5 in Great Yarmouth 7.4 in Norwich, and 17.0 in Barnsley; whooping-cough of 2.3 Middlesbrough, 2.5 in West Hartlepool. 2.7 in York, and 5.2 in Carlisle and diphtheria of $2 \cdot 3$ in St. Helens. The 936 cases of scarlet fever and 1616 of diphtberia under treatment in the Metropolitan Asylum Hospitals and the London Fever Hospital were 3 and 28 below the respective numbers remaining at the end of the previous week; ther were also 25 cases of small-pox under treatment on Saturday last including 15 new cases admitted during the week. Of the total death in the 96 towns 213 resulted from violence. The causes of 38 death were uncertified, of which 6 were registered in Liverposl and 4 in Birmingham.

Scotch Towns.-In the 16 largest Scotch towns, with an agregato population estimated at nearly $2,500,000$ persons, the anmual rate mortality was 13.9 , against 14.0 and 14.6 per 1000 in the two pre coding weeks. The 320 deaths in Glasgow corresponded to an annus rate of 15.0 per 1000 , and included 7 from measles, 5 from whooping. cough, 4 from infantile diarrhoea, and 1 each from enteric fever and diphtberia. The 73 deaths in Edinburgh were equal to a rate of 11: per 1000 , and included a fatal case of scarlet fever.

Irish Towns. - The 168 deaths in Dublin corresponded to an annus rate of 22.0 , or $2 \cdot 3$ per 1000 below that recorded in the previous weel and included 6 from whooping-cough and 1 each from measles and scarlet fever. The 190 deaths in Belfast were equal to a rate of $25 \%$ per 1000 , and included 19 from whooping-cough, 6 from measles, 2 from infantile diarrhcea, and 1 from diphtheria.

Hospital Sundar Fund at BRIstol.-The Hos pital Sunday collections in Bristol for 1918 amounted to $£ 3634$, which is $£ 473$ higher than any previous rear. Ther are a few collections still to be reported. 